\title{
Osteoarthritis linkage scan: more loci for the geneticists to investigate
}

\section{$\mathrm{J}$ Loughlin}

\section{Chromosomal loci potentially harbour osteoarthritis susceptibility genes, as shown by a genomewide linkage scan}

7 hose investigating the molecular genetic basis of osteoarthritis must believe that all the hard work is beginning to reap rewards, as yet another linkage scan shows several interesting chromosomal loci potentially harbouring osteoarthritis susceptibility. In the September issue of the Annals of Rheumatic Diseases, Greig et al ${ }^{1}$ reported the results of a comprehensive genomewide linkage scan performed on 202 families that contain individuals with nodal osteoarthritis, recruited from Nottinghamshire, UK. ${ }^{1}$ By using both a qualitative analysis (presence or absence of nodal osteoarthritis) and a quantitative analysis (severity of the disease), major hits were reported for chromosomes 3, 4, 8, 11 and 16. Intriguingly, the chromosome 3 and 16 hits overlap with osteoarthritis loci reported by other groups, implying that at least these two linkages are likely to be genuine.

\section{CURRENT STATUS OF GENETIC SUSCEPTIBILITY OF OSTEOARTHRITIS}

So how does this latest linkage data fit in with what we currently know about the molecular genetic basis of osteoarthritis susceptibility? The Greig et al report $^{1}$ is the fifth genomewide osteoarthritis linkage scan so far published, the others being conducted on affectedrelative pairs collected in the $\mathrm{UK}^{2}{ }^{3}$ Finland, ${ }^{4}$ Iceland $^{5}$ and the USA. ${ }^{67}$ The UK scan was performed on patients who had osteoarthritis of the hip or knee; other scans performed on patients with osteoarthritis of the hand were ascertained using a global hand osteoarthritis score or by focusing on particular joints of the hand. There have also been two gene-based association scans, the first performed on Japanese patients who had osteoarthritis of the hip or knee, ${ }^{8}$ and the second on UK Caucasian patients who had osteoarthritis of the knee. ${ }^{9}$ The linkage and association scans uncovered several important loci, which have subsequently yielded several susceptibility genes. The most compelling findings are the secreted frizzled-related protein 3 gene $F R Z B$ on chromosome $2 \mathrm{q}^{10-14}$ the interleukin-1 gene cluster on chromosome $2 \mathrm{q}^{15-18}$ the asporin gene ASPN on chromosome $9 \mathrm{q},{ }^{19}$ the metalloprotease gene $A D A M 12$ on chromosome $10 \mathrm{q},{ }^{20}$ the leucine-rich repeats and calponin homology domain containing protein 1 gene LRCHI on chromosome $13 \mathrm{q},{ }^{9}$ and the calmodulin-1 gene CALMI on chromosome 14q. ${ }^{8}$

What makes a finding compelling? Two things-(1) the significance of the result obtained and (2) the independent confirmation by another group of an original finding. The most compelling data regarding significance come from the ASPN study, with p values $<0.001$ for the association with osteoarthritis of a functional repeat polymorphism in the coding region of the gene. The most compelling finding with regard to independent confirmation is the FRZB association, which was originally reported in UK Caucasians and which has now been confirmed in studies carried out in The Netherlands, Belgium and the USA. Sometimes strong significance and independent confirmation do not go together. For example, the compelling $A S P N$ and CALMI associations were identified in Japanese patients but have not been replicated in Europeans. ${ }^{21-24}$ This implies the existence, at different frequencies between Asians and Europeans, of other polymorphic loci that act epistatically with $A S P N$ and CALMI to influence the osteoarthritis risk mediated by these two genes. Furthermore, non-genetic (environmental) differences between the two populations may also affect the penetrance of the $A S P N$-encoded and CALMI-encoded osteoarthritis susceptibility. We should therefore not necessarily expect to replicate a positive finding in all ethnic groups. ${ }^{25}$

\section{THE LATEST LINKAGE REPORT}

The Greig et al study is one step away from the above association analyses in that it has defined new chromosomal regions, each of which contains tens if not hundreds of genes. Therefore, there is still work for the geneticists to do in characterising the osteoarthritis susceptibility at each locus. Do any of the five loci detected by Greig et al overlap with any of the genes listed above? No. The chromosome 16 linkage does, however, overlap with a linkage reported in an Icelandic family with early-onset osteoarthritis. ${ }^{26}$ This region was also linked to disease in the UK large-joint scan, ${ }^{27}$ with the investigators subsequently reporting an association with single-nucleotide polymorphisms in the interleukin 4 receptor gene $I L 4 R .^{28}$ Analysis of $I L 4 R$ by Greig et al is therefore called for, although it needs to be borne in mind that another gene within the interval could also encode osteoarthritis susceptibility, as the original $I L 4 R$ association has not yet been independently replicated.

The quantitative analysis conducted by Greig et al focused on three specific osteoarthritis traits: distal interphalangeal nodes, joint space narrowing and osteophytes. A very important observation from this quantitative analysis was the limited overlap seen in the loci detected by the three traits. For example, the chromosome 16 linkage was restricted to the joint space narrowing trait, whereas the chromosome 8 linkage was principally accounted for by the distal interphalangeal node trait. This implies a very specific effect of each susceptibility locus, with their coinheritance in an individual tipping the balance towards overt, clinical disease. This aspect of the study by Greig et al merits further epidemiological investigation by them and by others.

\section{SUMMARY}

The findings by Greig et al provide us with new loci to investigate and also stimulate our thoughts relating to the overall nature of genetic susceptibility of osteoarthritis. Clearly, osteoarthritis is a complex disease both clinically and genetically. It is also clear that genetic studies are providing us with new insights into the fundamental causes of this disease. The recent advances in human molecular genetics exemplified by the sequencing of the human genome project, the delineation of the human HapMap and the development of high-throughput genotyping platforms now provide us with an opportunity to comprehensively search the genome for osteoarthritis risk alleles. The Greig et al study represents another step towards this goal.

\section{ACKNOWLEDGEMENTS}

Research into Ageing and the Arthritis Research Campaign supported these studies.

Ann Rheum Dis 2006;65:1265-1266.

doi: 10.1136/ard.2006.053967 
Correspondence to: J Loughlin, Institute of Musculoskeletal Sciences, Botnar Research Centre, Nuffield Orthopaedic Centre, University of Oxford, Oxford OX3 7LD, UK;

john.loughlin@ndos.ox.ac.uk

Accepted for publication 15 May 2006

Competing interests: None declared.

\section{REFERENCES}

1 Greig C, Spreckley K, Aspinwall R, Gillaspy E, Grant $M$, Ollier W, et al. Linkage to nodal osteoarthritis: quantitative and qualitative analyses of data from a whole genome screen identifies trait dependent susceptibility loci. Ann Rheum Dis 2006;65:1131-8.

2 Chapman K, Mustafa Z, Irven CM, Carr AJ, Clipsham K, Smith A, et al. Osteoarthritissusceptibility locus on chromosome $11 \mathrm{lq}$, detected by linkage. Am J Hum Genet 1999;65:167-74.

3 Loughlin J, Mustafa Z, Irven C, Smith A, Carr AJ, Sykes CK. Stratification analysis of an osteoarthritis genome screen - suggestive linkage to chromosomes 4, 6 and 16. Am J Hum Genet 1999;65:1795-8.

4 Leppävuori J, Kujala U, Kinnunen J, Kaprio J, Nissilä $M$, Heliövaara $M$, et al. Genome scan for predisposing loci for distal interphalangeal joint osteoarthritis: evidence for a locus on 2q. Am J Hum Genet 1999;65:1060-7.

5 Stefánsson $\mathrm{SE}$, Jönsson $\mathrm{H}$, Ingvarsson $\mathrm{T}$, Manolescu I, Jónsson $\mathrm{HH}$, Olafsdóttir $\mathrm{G}$, et al. Genomewide scan for hand osteoarthritis: a novel mutation in Matrilin-3. Am J Hum Genet 2003;72: 1448-59.

6 Demissie S, Cupples LA, Myers R, Aliabadi P Levy D, Felson DT. Genome scan for quantity of hand osteoarthritis. Arthritis Rheum 2002;46:946-52.

7 Hunter DJ, Demissie S, Cupples LA, Aliabadi P, Felson DT. A genome scan for joint-specific hand OA susceptibility. Arthritis Rheum 2004;50:2489-96.

8 Mototani H, Mabuchi A, Saito S, Fujioka M lida A, Takatori $Y$, et al. A functional single nucleotide polymorphism in the core promoter region of CALM1 is associated with hip osteoarthritis in Japanese. Hum Mol Genet 2005; 14:1009-17.

9 Spector TD, Reneland RH, Mah S, Valdes AM Hart DJ, Kammerer S, et al. Association between a variation in $\mathrm{LRCH} 1$ and knee osteoarthritis. Arthritis Rheum 2006;54:524-32.

10 Loughlin J, Dowling B, Chapman K, Marcelline L, Mustafa Z, Southam L, et al. Functional variants within the secreted frizzled-related protein 3 gene are associated with hip osteoarthritis in females. Proc Natl Acad Sci USA 2004; 101:9757-62.

11 Min JL, Meulenbelt I, Riyazi N, Kloppenburg M, Houwing-Duistermaat JJ, Seymour AB, et al. Association of the frizzled-related protein gene with symptomatic osteoarthritis at multiple sites. Arthritis Rheum 2005:52:1077-80.

12 Lories RJ, Boonen S, Peeters J, De Vlam K, Luyten FP. Evidence for a differential association of the Arg200Trp single-nucleotide polymorphism in FRZB with hip osteoarthritis and osteoporosis. Rheumatology 2006:45:113-14.

13 Lories RJ, Tylzanowski P, Reekmans K, Peeters J, Thomas TT, Luyten FP. sFRP3 knockout mice develop accelerated cartilage breakdown in experimental models of osteoarthritis. Arthritis Rheum. 2005;52: abstract 620, (Suppl).

14 Lane NE, Lian K, Nevitt MC, Zmuda JM, Lui L, Li J, et al. Frizzled-related protein variants are risk factors for hip osteoarthritis. Arthritis Rheum 2006:54: 1246-54.

15 Loughlin J, Dowling B, Mustafa Z, Chapman K. Association of the interleukin-1 gene cluster on chromosome 2q13 with knee osteoarthritis. Arthritis Rheum 2002:46:1519-27.

16 Meulenbelt I, Seymour AB, Nieuwland $M$, Huizinga TWJ, van Duijn CM, Slagboom PE. Association of the interleukin-1 gene cluster with radiographic signs of osteoarthritis of the hip. Arthritis Rheum, 2004:50;1179-86.

17 Smith AJP, Keen ப, Billingham MJ, Perry MJ, Elson CJ, Kirwan JR, et al. Extended haplotypes and linkage disequilibrium in the ILIRI-ILIA-ILIB ILIRN gene cluster: association with knee osteoarthritis. Genes Immun 2004:5:451-60

18 Smith AJP, Elson CJ, Perry MJ, Bidwell JL. Accuracy of haplotype association studies is enhanced by increasing number of polymorphic loci examined: comment on the article by Meulenbelt et al. Arthritis Rheum 2005;52:675.
19 Kizawa H, Kou I, lida A, Sudo A, Miyamoto Y, Fukuda A, et al. An aspartic acid repeat polymorphism in asporin inhibits chondrogenesis and increases susceptibility to osteoarthritis. Nat Genet 2005;37:138-44

20 Valdes AM, Van Oene M, Hart DJ, Surdulescu GL, Loughlin J, Doherty $M$, et al. Reproducible genetic associations between candidate genes and clinical knee osteoarthritis in men and women. Arthritis Rheum 2006;54:533-9.

21 Mustafa Z, Dowling B, Chapman K Sinsheimer JS, Carr A, Loughlin J. Investigating the aspartic acid (D) repeat of asporin as a risk factor for osteoarthritis in a UK Caucasian population. Arthritis Rheum 2005;52:3502-6.

22 Kaliakatsos $M$, Tzetis M, Kanavakis E, Fytili $P$, Chouliaras G Karachalios T, et al. Asporin and knee osteoarthritis in patients of Greek origin. Osteoarthritis Cartilage 2006; 14:609-11.

23 Rodriguez-Lopez J, Pombo-Suarez M, Liz M, Gomez-Reino JJ, Gonzalez A. Lack of association of a variable number of aspartic acid residues in the asporin gene with osteoarthritis susceptibility: case-control studies in Spanish Caucasians. Arthritis Res Ther 2006;8:R55.

24 Loughlin J, Sinsheimer JS, Carr A, Chapman K. The CALMI core promoter polymorphism associated with hip osteoarthritis in Japanese is not associated with hip osteoarthritis in a United Kingdom Caucasian population. Osteoarthritis Cartilage 2006; 14:295-8.

25 Spector T, Ahmadi KR, Valdes AM. When is a replication not a replication? Or how to spot a good genetic association study. Arthritis Rheum 2006:54:1051-4

26 Ingvarsson T, Stefánsson SE, Gulcher JR, Jónsson $\mathrm{HH}$, Jónsson $\mathrm{H}$, Frigge $\mathrm{ML}$, et al. A large Icelandic family with early osteoarthritis of the hip associated with a susceptibility locus on chromosome 16p. Arthritis Rheum 2001;44:2548-55.

27 Forster T, Chapman K, Marcelline L, Mustafa Z, Southam L, Loughlin J. Finer linkage mapping of primary osteoarthritis susceptibility loci on chromosomes 4 and 16 in families with affected women. Arthritis Rheum 2004;50:98-102.

28 Forster T, Chapman K, Loughlin J. Common variants within the interleukin 4 receptor $\alpha$ gene (IL4R) are associated with susceptibility to osteoarthritis. Hum Genet 2004;114:391-5. 